\title{
EFFECT OF AN TIOXIDANTS ON THE STABILITY OF PITCH-BASED POLYMER TO THERMO-OXIDATIVE ACTION
}

\author{
Iryna Krutko1, * , Kateryna Yavir ${ }^{1}$, Viacheslav Kaulin $^{1}$, Michal Strankowski $^{2}$
}

https://doi.org/10.23939/chcht12.01.109

\begin{abstract}
The influence of stabilizers - hydrogen donors - on the processes of thermooxidative destruction of pitch-based polymer has been investigated. It is shown that Irganox has not stabilizing effect on pitch-based polymer and melamine slightly retards the destructive process. A mixture of melamine and Irganox exhibits synergetic stabilizing effect and at the optimum ratio it can be used to prevent unwanted thermooxidative processes during pitch-based polymer preparation.
\end{abstract}

Keywords: pitch, pitch-based polymer, destruction, stabilizer, Irganox, melamine.

\section{Introduction}

Pitch-based polymer - a new class of thermoplastic polymeric materials is based on coal tar pitch. Coal tar pitch is a by-product of coal processing. It is formed in the production of coke for steel industry. Coal tar pitch is a complex heterogeneous system of highly condensed aromatic and heterocyclic compounds. Its chemical properties are characterized by the group composition. Coal tar pitch consists of several groups of compounds: $\gamma$-fraction, $\beta$-fraction, $\dot{\alpha}_{2}$-fraction and $\dot{\alpha}_{1}$-fraction. As it is known, coal tar pitch has weak polymer properties, which are largely dependent on the amount and composition of these fractions [1]. Some researchers represent coal tar pitch as a complex polymer formation, which is in the amorphous-crystalline phase state [2].

Coal tar pitch (further pitch) is cheaper then classical polymers. It is characterized by chemical and biological stability, has low thermal conductivity. However, its polymeric properties do not meet the requirements of modern polymeric materials. Feature of composition and properties of the pitch determine its extreme reactivity $[3,4]$. It has enabled to develop and

\footnotetext{
${ }^{1}$ Donetsk National Technical University,

2, Shybankova St., 85300 Pokrovsk, Ukraine

${ }^{2}$ Gdansk University of Technology,

$11 / 12$, G. Narutowicza St., Gdansk, Poland

*poshuk-doc@yandex.ua

(c) Krutko I., Yavir K., Kaulin V., Strankowski M., 2018
}

offer a new direction of using pitch - obtaining pitchbased polymers [5].

Pitch-based polymer is a product of lowtemperature modification of coal tar pitch by active polymers. It is obtained by a dispersion mixing of the pitch with polymers containing active functional groups (PVC, acetoxy group or maleic group).The process of the pitch-based polymer forming is realized at low temperatures (to $443 \mathrm{~K}$ ). By varying the process technological parameters and the ratio of the pitch and polymers in the mixture the pitch-based polymers with different properties can be prepared [6].

Modification of the pitch by PVC allows to obtain a new thermoplastic material - pitch-based polymer with improved mechanical and thermal properties $[7,8]$. Pitchbased polymer could be a precursor to produce a wide range of carbon materials: pitch composites, carbon fibers, porous materials, adsorbents and others.

During preparation and processing the pitch-based polymer is subjected to various unfavorable factors: heat, oxygen, mechanical loads that may negatively affect its properties. Under the influence of these factors in the pitch-based polymer two processes may take place together: destruction and structuring.

Destruction and structuring cause a change in the molecular and supramolecular structure in the pitch-based polymer. This leads to the deterioration of its performance properties: decreasing of mechanical strength, losing of elasticity, changing a surface state.

To slow down and prevent unwanted thermal oxidation processes at the stage of the pitch preparation it should be injected into substances that promote stabilization and preservation of the obtained material properties.

The most common class of heat stabilizers used for polymers are antioxidants of the first type [9].

This work is devoted to research of antioxidants influence on the stability of pitch-based polymer to thermooxidative action.

\section{Experimental}

To prepare the pitch-based polymer, the coal tar pitch and suspension PVC were used. 
Characteristics of the coal tar pitch: Vicat softening point $326 \mathrm{~K}$; viscosity at $408 \mathrm{~K}-10 \mathrm{~Pa} \cdot \mathrm{s}$; density $1300 \mathrm{~kg} / \mathrm{m}^{3}$; group composition, $\%$ : $\alpha_{1}$-fraction -8 ; $\alpha_{2}$-fraction $-27 ; \beta$-fraction $-34 ; \gamma$-fraction -31 .

PVC characteristics: Fikentcher constant $K_{F}=63$; bulk density $-0.5 \mathrm{~kg} / \mathrm{m}^{3}$.

Irganox 1010 and melamine were chosen as the stabilizers. It is the first type of antioxidants that act as hydrogen donors.

Irganox 1010 (Fig.1) belongs to a group of substituted phenols (phenolic antioxidants) with substituents sterically protecting the $\mathrm{OH}$ group(shielded phenols). Irganox-1010 - white, free-flowing powder; molecular weight $1178 \mathrm{~g} / \mathrm{mol}$; melting point 383-398 K; flash point $570 \mathrm{~K}$; density at $293 \mathrm{~K}-1150 \mathrm{~kg} / \mathrm{m}^{3}$; bulk density $530-630 \mathrm{~kg} / \mathrm{m}^{3}[9]$.

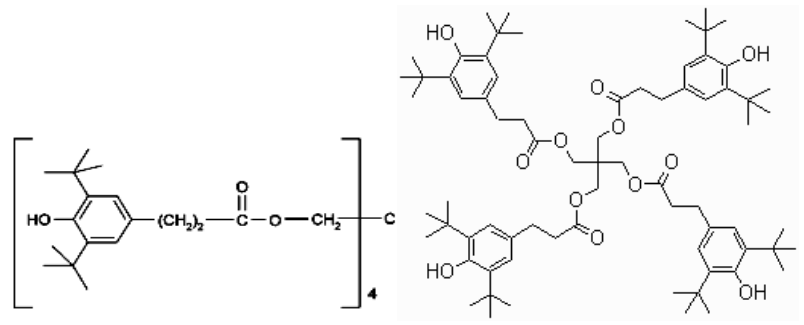

Fig. 1. Chemical and structural formula of Irganox 1010

Melamine belongs to aromatic amines (Fig 2). Molecular weight $126 \mathrm{~g} / \mathrm{mol}$; colorless crystals; melting point $637 \mathrm{~K}$ (with decomposition); density $-1571 \mathrm{~kg} / \mathrm{m}^{3}$.<smiles>Nc1nc(N)nc(N)n1</smiles>

Fig. 2. The structural formula of melamine

To obtain the pitch-based polymer a mixture of pitch and PVC was prepared. Preparation of the mixture was carried out by dispersion mixing the pitch with PVC ( 3 wt \% relative to a pitch) until a homogeneous mass. Then the obtained mixture was heated at a temperature of $423 \mathrm{~K}$ in the reactor for $1 \mathrm{~h}$.

When using the stabilizer (Irganox, melamine) at first a mixture of PVC with stabilizers was prepared, which is then was added to a pitch. By dispersion mixing a homogeneous mixture was prepared which was kept in the reactor at $423 \mathrm{~K}$ for $1 \mathrm{~h}$.

To assess the effectiveness of the stabilizers the weight change of investigated materials was chosen as the criterion. Changing the sample weight was determined in accordance with the requirements of GOST 12020, ISO 11358, ISO/DIS 9924, DIN 51006, ASTME 1131.

Thermal processes in the mixture of the pitch, PVC and stabilizer were studied by a thermogravimetric method on the instrument NETZSCH TG 209 F3 Tarsus in accordance with standards ISO 11358, ISO/DIS 9924, DIN 51006, ASTM E 1131.Experimental conditions: medium nitrogen; heating rate $-10 \%$; heating to $1073 \mathrm{~K}$.

\section{Results and Discussion}

During the modification of the pitch by PVC upon heating in the mixture two competing processes occur simultaneously: destruction (breaking of bonds in macromolecules and supramolecular structures) and structuring (the formation of more complex structures). Depending on conditions, one or another process may predominate that will be expressed in weight change of the investigated mixture. In the case of the predominance of destructive processes the mixture weight will be decreased.

The weight loss of the pitch-based polymer upon heating without the stabilizer was on average $0.53 \%$. At high temperature upon obtaining the pitch-based polymer, the chemical transformations occur mainly due to thermooxidative degradation. On the DTG curve (Fig. 3) for a mixture of pitch-PVC in the range of 508-523 K the peak is observed that indicates a sharp increase of decomposition rate of PVC.

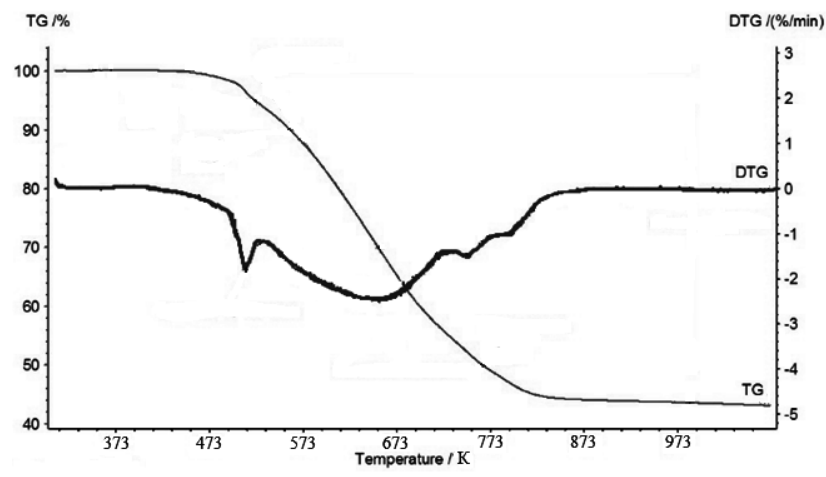

Fig. 3. DTG curve for a mixture,wt parts: pitch -100, PVC -3

At the same time under heating the coal tar pitch in an inert atmosphere, hydrogen and alkyl groups are detached to form the radicals. This occurs due to the low binding energy $\mathrm{C}-\mathrm{H}$ in polynuclear aromatic compounds. During decomposition of PVC a lot of active radicals are generated in the mixture. Formed radicals take part in the processes of chemical interaction with the pitch components. Polymeric 
radicals PVC initiate degradation reactions forming low molecular volatile compounds. Thermal degradation and thermo-oxidative degradation of coal tar pitch and PVC are developed through regularities of the radical chain process. In the presence of oxygen, a reactivity of pitch hydrocarbons increases. Because of the polycondensation processes and recombination of formed free radicals the more condensed compounds are obtained. As the more condensed compounds have an even higher energy delocalization, on the periphery of macromolecules the destructive processes are intensified. DTG curve (Fig. 3) indicates that eventually at a temperature above $833 \mathrm{~K}$ the process is finished by weight loss of more than $55 \%$.

Inhibition of thermal oxidation process by antioxidants (first type) means the detach of the hydrogen atom by the polymeric radical from antioxidant molecules. Radical antioxidant activity must be lower than the activity of the radical with which it reacts. Antioxidants can also react with the radicals to form inactive products.

Effect of the nature and amount of the stabilizer was studied using Irganox 1010 and melamine that were added in an amount of 2-4\% (relative to the pitch) in a mixture of the pitch and PVC. In all the cases weight loss of samples was observed. This could indicate predominance of destructive processes which were accompanied by the volatilization of low molecular weight products. However, the intensity of these processes has been different for the pitch-based polymer and mixture (the pitch-based polymer with a stabilizer).

Influence of the nature and quantity of stabilizers on the stability of the pitch-based polymer at a temperature of $423 \mathrm{~K}$ for $1 \mathrm{~h}$ is shown in Fig. 4 and Table 1.

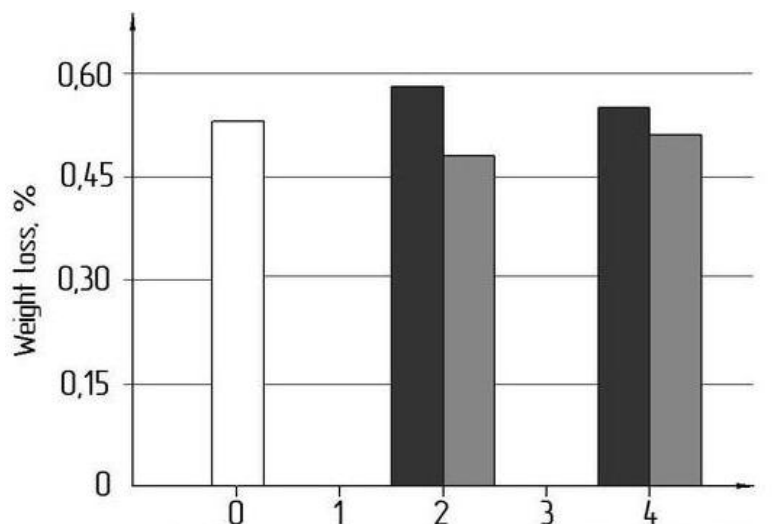

Amount of stabilizer, wt parts, for a mixture pitch - 100, PVC - 3 Without stabilizer Irganox - Melamine

Fig. 4. Effect of an amount of melamine and irganox 1010 on the weight loss of the pitch-based polymer at $423 \mathrm{~K}$
The obtained data show that the pitch-based polymer in its pure form has a smaller weight loss, than with Irganox. Irganox additive in an amount of 2-4\% initiates destructive processes, resulting in an increase of a weight loss 4-9\% as compared with the sample without the additive. The reason for this may be the ability of antioxidants of this type to be oxidized by oxygen to form highly active unwanted radicals, that launch a radicalchain mechanism of thermal degradation of the pitchbased polymer. As a result of these processes an amount of low molecular weight volatile substances and a weight loss increase. Melamine in an amount of $2-4 \%$ on the contrary slightly inhibits the destructive processes that leads to the decrease of the weight loss to $4-9 \%$ as compared with the sample without it.

Analysis of DTG curves (Figs. 5, 6) shows the presence of the peaks in the range of 508-523 K. Similar peaks were observed in the pitch-based polymer without antioxidant. This can indicate that the additives of melamine or Irganox $(2-4 \%)$ have practically no effect on the development of thermochemical destructive processes. However, on the thermogram (Fig. 7) in which Irganox and melamine are used as a stabilizer mixture, this peak is absent. Thus, we can be concluded that the complex stabilizer (a mixture of Irganox and melamine) can slow the degradation processes, resulting in the formation of low molecular weight volatiles.

Table 2 shows that in the range of $510-512 \mathrm{~K}$ a weight loss rate of the pitch-based polymer as a result of destruction is $1.7-1.8 \% / \mathrm{min}$ in the presence of melamine or Irganox and without them. Although at the content of $4 \%$ melamine it is lower $(1.5 \% / \mathrm{min})$. The use of melamine or a mixture (melamine and Irganox) increases the temperature (at which the weight loss is $5 \%$ ) from 4 to 6 degrees.

As we can see from the results shown in Table 3, the mixture of melamine and Irganox provides a synergistic stabilizing effect in the concentration range of $2-4 \%$.

A synergistic effect begins to appear when an amount of stabilizers is $5 \%$ as evidenced by weight loss decrease up to $28 \%$ as compared with a weight loss of the pitch-based polymer without stabilizers (Table 3, test 3).

Thermal degradation occurs as a radical chain process, wherein the step of initiation is disintegration of macromolecules to form radicals. Under the action of antioxidants pair (melamine and Irganox) a stop of the chain reaction occurs probably as a result of recombination and disproportionation of the radicals. Thus, the total rate of destructive processes is reduced as compared with the rate of these processes without antioxidants. However, the total effect is the predominance of destructive processes as compared with polycondensation (weight loss is observed), despite the decrease in their intensity. 
Table 1

Effect of the nature and amount of a stabilizer on the relative weight change of samples

\begin{tabular}{|c|c|c|c|c|}
\hline \multicolumn{5}{|c|}{ Composition, wt parts } \\
\hline Pitch & PVC & Irganox & Melamine & \multirow{2}{*}{ Relative weight change $\eta, \%$} \\
\hline 100 & 3 & 2 & 0 & +9 \\
\hline 100 & 3 & 4 & 0 & +4 \\
\hline 100 & 3 & 0 & 2 & -9 \\
\hline 100 & 3 & 0 & 4 & -4 \\
\hline
\end{tabular}

$\eta=\frac{m-m_{0}}{m_{0}} \cdot 100$, where $\eta-$ relative weight change as compared with a weight loss of the pitch-based polymer (without stabilizers), \%; $m_{0}-$ a weight loss of the pitch-based polymer without stabilizers, $\mathrm{g} ; m$ - a weight loss of the pitch-based polymer with stabilizers, $\mathrm{g}$.

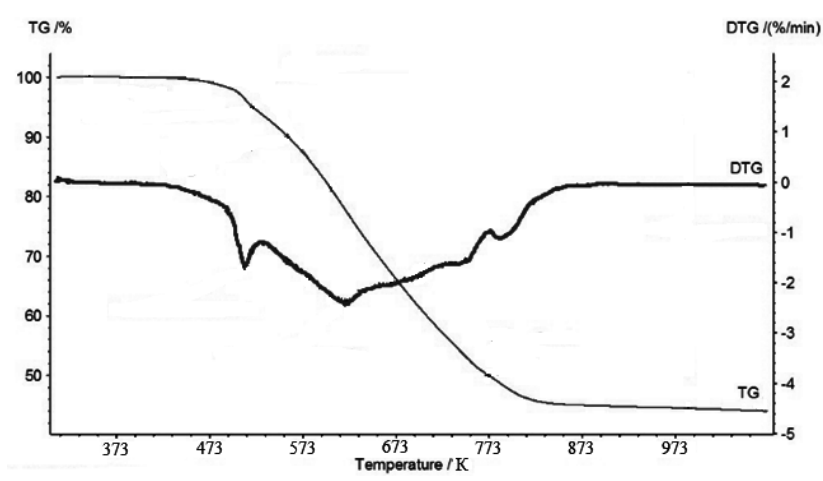

Fig. 5. DTG curve for a mixture, wt parts: pitch - 100; PVC - 3; Irganox - 2

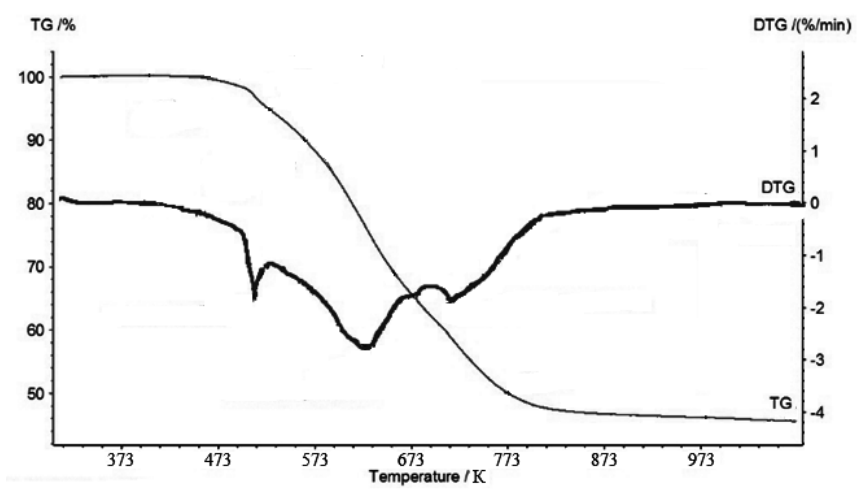

Fig. 6. DTG curve for a mixture, wt parts: pitch -100; PVC - 3; melamine - 2

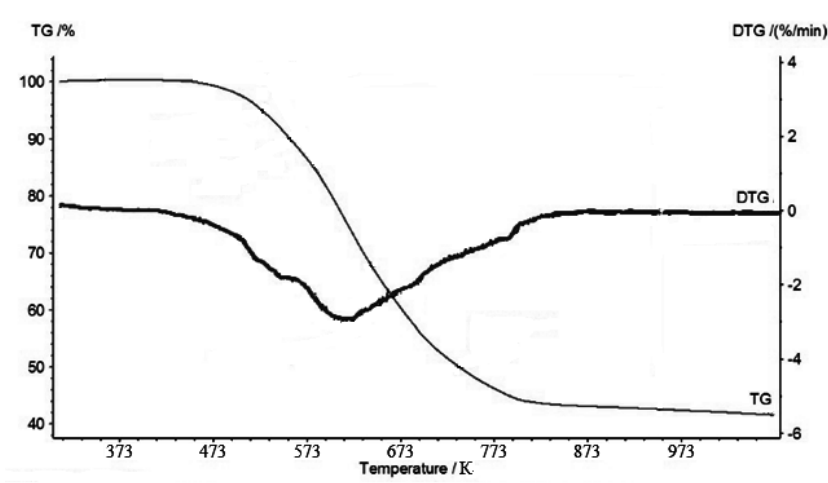

Fig. 7. DTG curve for a mixture, wt parts: pitch - 100; PVC - 3; Irganox - 4, melamine - 4

Table 2

Effect of the nature and amount of stabilizers on destructive processes of the pitch-based polymer

\begin{tabular}{|c|c|c|c|c|c|c|c|}
\hline \multirow{2}{*}{ No. } & \multicolumn{4}{|c|}{ Composition, wt parts } & \multirow{2}{*}{ Temperature, $\mathrm{K}$} & \multirow{2}{*}{$\begin{array}{c}\text { The rate of } \\
\text { weight loss, } \% / \mathrm{m}\end{array}$} & $\begin{array}{c}\text { Temperature of } \\
\text { weight loss }(5 \%), \mathrm{K}\end{array}$ \\
\cline { 2 - 5 } & Pitch & PVC & Irganox & Melamine & & 1.8 & 519 \\
\hline 1 & 100 & 3 & 0 & 0 & 512 & 1.7 & 519 \\
\hline 2 & 100 & 3 & 2 & 0 & 511 & 1.8 & 519 \\
\hline 3 & 100 & 3 & 4 & 0 & 511 & 1.8 & 525 \\
\hline 4 & 100 & 3 & 0 & 2 & 510 & 1.5 & 524 \\
\hline 5 & 100 & 3 & 0 & 4 & 510 & - & 523 \\
\hline 6 & 100 & 3 & 2 & 2 & 510 & - & 525 \\
\hline 7 & 100 & 3 & 4 & 4 & 510 & & \\
\hline
\end{tabular}


Table 3

Effect of the nature, amount and ratio of stabilizers in the mixture on the relative weight change of samples

\begin{tabular}{|c|c|c|c|c|c|c|}
\hline \multirow[t]{2}{*}{ No. } & \multicolumn{4}{|c|}{ Composition, wt parts } & \multirow{2}{*}{ Weight loss, $\%$} & \multirow{2}{*}{$\begin{array}{c}\text { Relative weight } \\
\text { change } \eta, \%\end{array}$} \\
\hline & Pitch & PVC & Irganox & Melamine & & \\
\hline 1 & 100 & 3 & 2 & 0 & 0.58 & +9 \\
\hline 2 & 100 & 3 & 2 & 2 & 0.55 & +4 \\
\hline 3 & 100 & 3 & 2 & 3 & 0.38 & -28 \\
\hline 4 & 100 & 3 & 2 & 4 & 0.42 & -21 \\
\hline 5 & 100 & 3 & 4 & 0 & 0.55 & +4 \\
\hline 6 & 100 & 3 & 4 & 2 & 0.32 & -40 \\
\hline 7 & 100 & 3 & 4 & 3 & 0.35 & -34 \\
\hline 8 & 100 & 3 & 4 & 4 & 0.50 & -6 \\
\hline
\end{tabular}

It should be noted that increasing the proportion of melamine (Table 3, tests 3-4 and 6-8) in the mixture with Irganox (Irganox content is $2-4 \%$ ) leads to a slight activation of destructive processes as indicated by the relative weight change.

At the content of $6 \%$ stabilizers (Table 3, tests 4,6 ) the greatest synergistic effect was detected if the mixture of stabilizers contained Irganox $67 \%$ and melamine $33 \%$ (Table 3, test 6) because a maximum decrease in mass loss up to $40 \%$ (as compared to weight loss of the pitch-based polymer without stabilizers) was observed.

\section{Conclusions}

Upon heating the pitch-based polymer as well as the mixture of antioxidants and the pitch-based polymer a weight loss of samples was observed. This indicates the predominance of destructive processes that are accompanied by the volatilization of low molecular weight products. However, the intensity of these processes has been different for the pitch-based polymer without stabilizers and with them.

The use of melamine and Irganox 1010 separately does not prevent the development of thermochemical destructive processes, i.e. they do not have an inhibitory effect upon heating the pitch-based polymer.

Irganox and melamine - a pair of antioxidants of the same action mechanism, show a synergistic effect that is expressed in a decrease of weight loss for the pitchbased upon heating. The mixture of antioxidants (melamine and Irganox) slows down the overall rate of the degradation reactions.

Based on the performed researches it is shown that the mixture of antioxidants (melamine and Irganox) at the optimum ratio can be used to prevent unwanted thermal- oxidative processes for the preparation stage of the pitchbased polymer.

\section{References}

[1] Krutko I. KaulinV.: Naukovi Pratsi DonNTU, 2010, 15, 103.

[2] Pitiulin I.: Naukovo-Tekhnichni Osnovy Stvorennia

Kamianovuhilnykh Vuhletsevykh Materialiv dlia

Velykohabarytnykh Elektrodiv. Kontrakt, Kharkiv 2008.

[3] Zielinski J., Ciesinska W., Polaczek J.: Pol. J. Appl. Chem., 2000, 44, 161.

[4] Beilina N., Ostrovsky D., Ostrovsky V.: Khimia Tverdogo

Topliva, 2002, 6, 62.

[5] Krutko I., Kaulin V., Satsiuk K.: Naukovi Pratsi DonNTU, 2011, 16, 150.

[6] Krutko I., Kaulin V., Satsiuk K.: Naukovi Pratsi DonNTU, 2012, 19, 133.

[7] Krutko I., Kaulin V., Satsiuk K.: Naukovi Pratsi DonNTU, 2013, 2, 161.

[8] Kaulin V.: East.-Eur. J. Enterprise Technol., 2015, 3/11, 29.

[9] Zweifel H., Mayer R., Schiller M.: Dobavki k Polymeram: Spravochnik. Professia, St. Petersburg 2010.

Received: February 02, 2017 / Revised: March 31, 2017 / Accepted: May 29, 2017

\section{ВПЛИВ АНТИОКСИДАНТІВ \\ НА СТАБІЛЬНІСТЬ ПЕКОПОЛІМЕРУ ДО ТЕРМООКИСНЮВАЛЬНОЇ ДІЇ}

Анотація. Досліджено вилив стабілізаторів - донорів гідрогену - на процеси термоокиснювальної деструкиії пекополімеру. Показано, щзо ірганокс не здійснює стабілізуючої дї на пекополімер, а меламін слабо уповільнюе деструктивні процеси. Встановлено, що суміш ірганоксу та меламіну виявляють синергічний стабілізуючий ефект $і$ за оптимального співвідношення вони можуть бути використані для запобігання небажаних термоокиснювальних процесів при приготування пекополімера.

Ключові слова: кам'яновугільний пек, пекополімер, деструкиія, стабілізатор, ірганокс, меламін. 